\title{
The Impact of Industrial Structure Upgrading on Guangdong's Export Scale
}

\author{
Jinfeng $\mathrm{Ou}^{1,2^{*}}$, Jiamin $\mathrm{Yan}^{1}$ \\ ${ }^{1}$ Business School, Lingnan Normal University, Zhanjiang 524048, Guangdong, China \\ ${ }^{2}$ Lingnan Normal University Guang Dong Coastal Economic Belt Development Research Center,Zhanjiang 524048 , \\ Guangdong, China \\ *Corresponding author. Email: oujf2008@foxmail.com
}

\begin{abstract}
Based on the panel data of Guangdong from 2005 to 2019, this paper makes an empirical study on the impact of industrial structure upgrading on Guangdong's export scale. The result shows that when the Theil index increases by 1 percentage point, the export will decrease by 3.15 percentage points. The closer the Theil index is to 0 , the higher the rationalization of industrial structure is; The upgrading level of industrial structure has a negative impact on export. When the upgrading level of industrial structure increases by 1 percentage point, export will decreases by 1.08 percentage points. The reason is that enterprises are easy to fall into "export dilemma" in the process of industrial upgrading. Therefore, it is suggested that Guangdong should rationalize its industrial structure and attach importance to regional heterogeneity in order to expand its export scale.
\end{abstract}

Keywords: Industrial structure transformation and upgrading, Export trade, Guangdong Province

\section{INTRODUCTION}

Since the reform and opening up, Guangdong Province has changed from a backward agricultural province to the largest economic province and a global manufacturing base in China, and has made progress towards a high-quality development road. The industrial structure has been inclined to focus on agriculture before the reform and opening up to the heavy industry after the reform and opening up, and now it is inclined to service industry. The three industrial structure of Guangdong Province has experienced the industrial pattern from "one, two three" to "three two one". The emerging industries and high-tech intensive industries have become the new growth points of Guangdong economy. At the same time, the total export volume increased from $\$ 101.40$ billion in 1987 to $\$ 629.46$ billion in 2020. The transformation and upgrading of industrial structure has attracted a wide range of attention on the impact of Guangdong export scale. How the transformation and upgrading of industrial structure will affect the export scale of Guangdong has become the focus of scholars' research. Based on panel data of Guangdong in 2005-2019, this paper studies the impact of industrial structure transformation and upgrading on Guangdong export scale, and puts forward relevant policy suggestions for coordinated development of Guangdong Province.

\section{LITERATURE REVIEW}

\subsection{Research on the influencing factors of industrial structure transformation and upgrading}

Hong Yinxing believes that the transformation and upgrading of industrial structure cannot be separated from marketization [1]. Michaely believes that export can optimize resource allocation and technology transfer, and promote the transformation and upgrading of industrial structure [2]. Kan Daxue concluded that the export of eastern China has a positive effect on the upgrading of manufacturing industrial structure [3]. Zuo Yonghua believes that the differences in export trade structure affect the upgrading and adjustment of regional industrial structure [4].To sum up, the existing literature focuses on multi-dimensional analysis of the influencing factors of industrial structure transformation and upgrading, some research emphasizes technology to promote the upgrading of industrial structure. 


\subsection{Research on the influencing factors of international trade}

Chen Ming et al. found that the openness of financial services industry has a positive impact on the upgrading of export product quality of manufacturing industry [5]. Based on the micro data, Mao Qilin found that FDI not only increases the proportion of export sales but also increases the export probability of enterprises [6]. Liu Xisong et al. studies the relationship between foreign trade and industrial structure and the results show that there is a long-term dynamic equilibrium relationship between the import and export and the tertiary industrial structure, and the two are mutually promoted, and the import and export trade has the most obvious interaction with the secondary industry [7]. Wang Ying et al. made an empirical analysis of the relationship between Shanxi Province's foreign trade structure and industrial structure, and concludes that the change of the export structure of leading industries in Shanxi Province plays a positive role in the change of industrial structure [8]. Ma zhengliang et al. analyzed the relationship between foreign trade and industrial structure from the theoretical and empirical dimensions, and concluded that China's foreign trade has a promoting role in upgrading the industrial structure and there is a smooth transmission mechanism between them [9].

\subsection{Mechanism analysis of the impact of industrial structure transformation and upgrading on export}

The transformation and upgrading of industrial structure makes China embed in the higher industrial value chain, improve our position in the global value chain and improve the competitiveness of export products. The essential resources will be transformed from resource, labor-intensive industry to capital and technology intensive industry, and the upgrading of industrial structure will be promoted continuously through the dynamic transformation of resources. Industrial structure is the basis of export structure, and industrial structure can influence export structure through product competitiveness. With the continuous development of emerging industries, the industrial structure is constantly transforming and upgrading, which promotes the upgrading of export industrial structure.

\section{EMPIRICAL ANALYSIS}

\subsection{Model specification}

The degree of rationalization of industrial structure and advanced level of industrial structure are regarded as the core variables, fiscal expenditure, loans, the actual use of foreign capital as the control variables, the econometric model are established as follow.ex is the export volume, measured by the amount of exports. $t l$ is the rationalization of industrial structure, measured by Theil entropy index.The specific calculation formula refers to the research of Gan Chunhui el al. [10].ts is the advanced level of industrial structure. The ratio of the added value of the tertiary industry to the added value of the secondary industry is used to measure the level of industrial structure upgrading. $w z$ is the actual utilization of foreign capital, loan is the amount of domestic and foreign currency loans, $c z z c$ is fiscal expenditure.

$$
\begin{aligned}
& \ln \text { ex }_{i t}=\beta_{0}+\beta_{1} t l_{i t}+\beta_{2} t s_{i t}+\beta_{3} \ln w z_{i t} \\
& +\beta_{4} \ln \operatorname{loan}_{i t}+\beta_{5} \ln c z z c_{i t}+\varepsilon_{i t}
\end{aligned}
$$

\subsection{Regression results}

\subsubsection{Overall regression results}

In order to examine the impact of the transformation and upgrading of industrial structure on Guangdong's exports, this paper takes the rationalization of industrial structure and the advanced level of industrial structure as the core variables, and takes the actual amount of foreign capital utilization, the amount of domestic and foreign currency loans, and fiscal expenditure as the control variables to conduct a stepwise regression analysis. The regression results are as follows.

It can be seen from table 1 (equation1- equation5) that with the constant addition of variables, the goodness of fit of the model is increasing, and the degree of fit of the model is ideal. The Theil index increases by 1 percentage point, the export will decrease by 3.15 percentage points, which means that the rationalization of industrial structure will play a positive role in promoting the export of Guangdong Province. After adding fiscal policy variables, the coefficient of industrial structure upgrading level becomes negative. The reason is that Guangdong Province is in the transformation stage, which will make more capital invested in capital intensive and technology intensive industries. In the short run, the cost of transformation and upgrading is high, and enterprises will fall into "export dilemma", so the impact effect is negative. In addition, the actual use of foreign capital will promote exports. When the actual use of foreign capital increases by $1 \%$, it will promote exports by $0.57 \%$. Similarly, the amount of domestic and foreign currency loans also has a positive impact on exports. When the amount of domestic and foreign currency loans increases by $1 \%$, it will promote exports by $0.66 \%$. 
Table 1 Results of regression analysis

\begin{tabular}{|c|c|c|c|c|c|c|}
\hline variable & 1 & 2 & 3 & 4 & 5 & 6 \\
\hline \multirow[t]{2}{*}{$t l$} & $-13.383^{* * *}$ & $-12.780^{\star \star *}$ & $-4.844^{\star \star \star}$ & $-1.888^{\star \star *}$ & $-3.146^{\star * *}$ & $1.031^{* \star \star}$ \\
\hline & $(-7.70)$ & $(-7.72)$ & $(-5.96)$ & $(-4.19)$ & $(-4.59)$ & $(-1.18)$ \\
\hline \multirow[t]{2}{*}{ ts } & & $2.005^{\star \star \star}$ & $0.932^{\star \star \star}$ & $-1.951^{\star \star \star}$ & $-1.080^{\star * *}$ & $-1.44^{\star * *}$ \\
\hline & & (2.81) & (3.16) & $(-7.62)$ & $(-2.73)$ & $(-3.38)$ \\
\hline \multirow[t]{2}{*}{$\ln w z$} & & & $0.849^{\star \star \star}$ & $0.173^{\star \star \star}$ & $0.568^{\star \star \star}$ & $3.976^{\star \star \star}$ \\
\hline & & & (17.15) & (3.13) & (9.59) & (16.47) \\
\hline \multirow[t]{2}{*}{ Inloan } & & & & $1.055^{\star \star \star}$ & $0.655^{\star \star \star}$ & $0.971^{\star \star \star}$ \\
\hline & & & & (13.55) & (1.55) & $(20.20)$ \\
\hline \multirow[t]{2}{*}{$\ln c z z c$} & & & & & $0.745^{\star \star \star}$ & $0.908^{\star \star \star}$ \\
\hline & & & & & $(6.21)$ & (13.41) \\
\hline \multirow[t]{2}{*}{ Constant } & $10.005^{\star * *}$ & $7.890^{\star \star \star}$ & $1.271^{\star *}$ & $-0.617^{* *}$ & -0.173 & $0.898^{\star \star *}$ \\
\hline & (24.63) & (9.33) & $(2.47)$ & $(-2.16)$ & $(-0.38)$ & (2.85) \\
\hline Observations & 315 & 315 & 315 & 315 & 315 & 315 \\
\hline R-squared & 0.506 & 0.566 & 0.931 & 0.984 & 0.959 & 0.982 \\
\hline
\end{tabular}

${ }^{*} P<0.1,{ }^{* *} P<0.05,{ }^{* * *} P<0.01$; the value in brackets is the standard deviation of the coefficient.

\subsubsection{Robustness analysis}

In order to verify the robustness of the above regression, this paper uses the calculation method of Han Yonghui et al. (2017) to remeasure the level of rationalization and upgrading of industrial structure. The details are as follows: using the deviation index of industrial structure to measure the rationality of industrial structure; The product of industrial output and labor productivity is used to measure the upgrading of industrial structure [11]. The empirical results are shown in Table1 (equation 6). At the significant level of $1 \%$, the rationalization of industrial structure increases by $1 \%$, the export volume will increase by $1.03 \%$, and the upgrading level of industrial structure increases by $1 \%$, the export volume will decrease by $1.44 \%$, which is basically consistent with the previous estimation, so the research has a certain robustness.

\section{CONCLUSION}

Based on the panel data of Guangdong in 20052019, this paper makes an empirical study on Guangdong export scale based on industrial structure upgrading, and concludes that the higher the rationalization of industrial structure, the more favorable it is for export; The higher the level of industrial structure, the negative correlation is found for Guangdong export; The actual foreign investment utilization has a small positive effect on Guangdong's export, while the loan amount of foreign currency has a significant promotion effect.The advanced level of industrial structure has a negative impact on Guangdong export, which is because Guangdong is in the process of transforming from "extensive" economy to "highquality" economy. Enterprises need to invest a lot of funds in scientific and technological innovation, and the average cost of products is relatively high in the short term, which is not conducive to the export of products. The actual foreign investment utilization has a slight positive effect on export, and the most positive effect is generated by the financial expenditure.

Based on the above conclusions, this paper puts forward the following two suggestions: first, promote the rationalization of industrial structure. Guangdong is in the forefront of economic development. It can not only rely on the development of industry and processing industry, but also need the coordinated development of the three industries. The government should actively guide the development of some leading industries with long-term development potential, pay attention to the scientific and technological research and development projects of the tertiary industry, view the transformation and upgrading of industrial structure from a long-term perspective, and drive export development by reducing the cost of industrial upgrading, promoting technological progress and technology spillover. 
Second, pay attention to regional heterogeneity. The Pearl River Delta is a key area of economic development. We should increase investment in hightech industries and accelerate the development of service industries. According to the regional characteristics, the eastern and northwestern regions of Guangdong should develop their industries according to local conditions, so as to realize the regional dislocation and coordinated development. For example, the mountainous areas in northern Guangdong have superior ecological environment and are suitable for the development of eco-tourism industry. The government should increase the construction of infrastructure in mountainous areas.

\section{AUTHORS' CONTRIBUTIONS}

The authors declare no conflict of interest and are responsible for the content of the manuscript.

\section{ACKNOWLEDGMENTS}

The research reported in this manuscript is supported by Youth Innovative Talent projects in Colleges and universities of Guangdong Province.

\section{REFERENCES}

[1] Hong Yinxing. Trade Structure Adjustment and Industrial Upgrade under WTO Conditions [J]. Management World, 2001 (02): 21-26 + 219220.DOI: 10.19744/j.cnki.11-1235/f.2001.02.004.

[2] Michaely M. Export and Growth : an empirical investigation $[\mathrm{J}]$. Journal of Development Economics, Vol.4, No.1, 1977, pp.49-53.DOI : 10.1016/0304-3878(77)90006-2.

[3] Kan Daxue. Empirical Study on the Relationship between Regional Foreign Trade and Manufacturing Industrial Structure-Based on Provincial Manufacturing Industry Dynamic Panel Data [J]. Technical economy, 2012,31 (04): 38-44 +125.DOI:https://kns.cnki.net/kcms/detail/detail.as px ? FileName $=$ JSJI201204008 $\&$ DbName $=$ CJFQ20 12

[4] Zuo Yonghua, Liu Binbin. Analysis of export trade structure and regional industrial structure [J]. Journal of Hebei University of Economics and Trade, $2019,40 \quad$ (01): $11-89$. DOI:https://kns.cnki.net/kcms/detail/detail.aspx?Fil eName $=$ HBJM201901012 \&DbName $=$ CJFQ2019

[5] Chen Ming, Zeng Chunyan, Yao Yangyang. Financial Services Opening and Manufacturing Enterprises Export Product Quality: Impact Mechanism and Experience Evidence [J]. Southern Economy 2021 (01):

64-
82.DOI:https://kns.cnki.net/kcms/detail/detail.aspx ?FileName $=$ NFJJ202101005 $\&$ DbName $=$ CJFQ202 1

[6] Mao Qixiang, Xu Jiayun. Has China's foreign direct investment promoted or curbed corporate exports? [J]. Quantitative Economic and Technical Economic Studies, 2014,31 (09): 3-21.DOI: https://kns.cnki.net/kcms/detail/detail.aspx?FileNa $\mathrm{me}=\mathrm{SLJY201409001} \& \mathrm{DbName}=\mathrm{CJFQ} 2014$

[7] Liu Xi Song, Qiu Rui. Dynamic Analysis of the Relationship between Chinese Foreign Trade and Industrial Structure $[\mathrm{J}]$. Statistics and Decision Making, $\quad 2009 \quad$ (04): $\quad 110$ 111.DOI:https://kns.cnki.net/kcms/detail/detail.asp $\mathrm{x}$ ?FileName $=$ TJJC200904040\&DbName $=$ CJFQ20 09

[8] Wang Ying, Cheng Yanping. Empirical Analysis of RelRelations between Foreign Trade and Industrial Structure in Shanxi Province [J]. Economic issues, $2018 \quad$ (06): 124 129.DOI:https://kns.cnki.net/kcms/detail/detail.asp $\mathrm{x}$ ?FileName $=$ JJWT201806022 \&DbName $=$ CJFQ20 18

[9] Ma Guoliang, Gu Guoda. An Empirical Study on the Relationship between Chinese Foreign Trade and Industrial Structure [J]. International Business (Journal of the University of Foreign Economics and Trade), $2011 \quad$ (06): 17-25. DOI:https://kns.cnki.net/kcms/detail/detail.aspx?Fil eName $=$ DWMY201106004\&DbName $=$ CJFQ2011

[10] Gan Chunhui,Zheng Ruogu, Yu Dianfan.The Influence of China's Industrial Structure Change on Economic Growth and Wave. [J]. Economic Studies, 2011,46(05):4-16+31.

DOI:https://kns.cnki.net/kcms/detail/detail.aspx?Fil eName $=$ JJYJ201105002\&DbName $=$ CJFQ2011

[11] Han Yonghui, Huang Liangxiong, Wang Xianbin. Did the industrial policies promote the upgrading of the local industrial structure? Theoretical Interpretation and Empirical Test Based on Developing Local Government [J]. Economic Studies, 2017, 52 (08): 33-48. DOI: http://kns.cnki.net/kcms/detail/detail.aspx?FileNam e=JJYJ201708004\&DbName=CJFQ2017 